\title{
Bacteriological Analysis of Well Water Sources in the Bambui Student Residential Area
}

\author{
Niba Rawlings Ngwa*, Nchang Chrysanthus \\ Department of Medical and Biomedical Science, National Polytechnic Bambui, Bamenda, Cameroon \\ Email: "rawlingston@yahoo.com,nbngwa@gmail.com
}

Received May 13, 2013; revised June 16, 2013; accepted July 12, 2013

Copyright (C) 2013 Niba Rawlings Ngwa, Nchang Chrysanthus. This is an open access article distributed under the Creative Commons Attribution License, which permits unrestricted use, distribution, and reproduction in any medium, provided the original work is properly cited.

\begin{abstract}
Majority of the population in the Bambui student residential area depend on wells as their source of water supply. Due to increasing complaints from students after using this well water sources, this study was carried out to examine the microbial quality of well water sources in the Bambui student residential area, Bamenda, Cameroon as a way of safe guarding public health against water borne diseases. Water samples from a total of fifteen wells, covered and uncovered were assessed for their bacteriological quality using the multiple tube fermentation technique to determine the coliform count using the most probable number method. Positive tubes of the presumptive test were further cultured on appropriate solid media. The organisms isolated were further characterized using standard procedures. The result of the study revealed that most of the wells were grossly contaminated with bacteria pathogens such as Klebsiella species (95\%), Escherichia coli (52\%) and Salmonella typhi (32.5\%). Comparatively, the uncovered wells were more contaminated with bacteria pathogens than the covered well. All the water samples except three exceeded the standard limit of the most probable number (MPN) per $100 \mathrm{ml}$ set for untreated drinking water by the World Health Organization. This result highlight the fact that most well water sources in the Bambui student residential area metropolis are not safe microbiologically for drinking without additional treatment such as boiling or disinfection and this could lead to outbreak of water borne diseases. Good and proper environmental and personal hygiene must be maintained especially by the users of these wells to prevent their contamination with bacterial pathogens. Wells should also be properly constructed.
\end{abstract}

Keywords: Well Water; Bacteriological Analysis; Bacterial Pathogens; Water Borne; Disease

\section{Introduction}

Water of good drinking quality is of basic importance to human physiology as well as indispensable to man's continued existence [1]. Domestic water is generally supplied to homes through private wells or public water companies. Water supplied by public water companies is usually safe to drink and does not pose a health risk. The quality of the water supplied by these companies is periodically checked. Water supplied by a private source is also usually safe to drink; however, it can be contaminated by harmful bacteria resulting from faulty septic tanks, chemicals from a toxic spill that occurred years before, leaking underground storage tanks, or pesticides and fertilizers. The only way to tell whether the water is potable is to have it tested. Unavailability of municipal water supply (provided by CDE) and lack of community water

\footnotetext{
"Corresponding author.
}

supply to the Bambui student residential area, resulting to the use of untreated well water sources have pose a great health risk to the members of this community. There have been a lot of complains on health problems such as skin rashes, abdominal discomfort and others by students after using well water sources for drinking bathing and other domestic purposes. Guideline for bacteriological water differs from country to country but they all conform to WHO recommendation. The standards for drinking water are more stringent than those for recreational waters.

\section{Materials and Methods}

\subsection{Study Area and Sampling}

Water samples from fifteen wells were randomly collected for bacteriological analysis. Well water constitutes the major source of drinking, bathing and other domestic purposes in this area. Most of the wells under study were 
privately owned and are usually open to general public. One quarter of the number of the studied wells were covered while the others were not. Drawing of water from these wells was done by the use of $10-15$ litre containers, which is tied directly to the well cover. In certain cases where this is not possible, individual fetchers usually come with small buckets to draw water. The wells are not less than 2 years old. The surrounding of the closed wells was clean and even cemented but that of the uncovered wells had some vegetation growing around. There is a need therefore to have water supply surveillance as a way of keeping a careful watch at all times from the public health point of view, over the safety and acceptability of drinking water supplies [2].

\subsection{Collection of Water Samples}

Water samples were collected in sterile bottles. For uncovered wells, the bottles were tied with a strong string to a piece of metal (about $500 \mathrm{~g}$ ) as the weight. The bottle cap was aseptically removed and the weighted bottle lowered into the well to a depth of about 1 - 2 meters. The bottle was brought up to a surface and covered with a screw cap when no air bubbles were seen inside.

\subsection{Identification of Isolates}

Positive tubes of the presumptive test were subcultured on eosin methylene blue (EMB) agar for the enumeration of Escherichia coli and other enteric coliforms. All the inoculated media were incubated aerobically at $37^{\circ} \mathrm{C}$ for 24 - 48 hours, after which the isolates were further characterized by a combination of colonial and morphological characteristic on solid media, biochemical tests, as described by Cowan and Stell [3-5], as well as a sub culture on Klinger Iron agar (KIA) which showed a distinctive characteristic on the butt, slope and hydrogen sulphite gas production.

\section{Results}

Water quality analysis was based on the most probable number (MPN) method (multiple tube fermentation technique), which estimates the concentration of viable total coliforms (TCs) and Escherichia coli per $100 \mathrm{ml}$ in Table 1. A combination of media, Mac Conkey and Eosin methylene blue (EMB) were utilized. Both media which simultaneously detect total coliforms in water are formulated to minimize interference from non-coliform bacteria and have almost similar sensitivity and specificity.

\subsection{Bacteriology}

Total bacterial count: For each water sample, $1 \mathrm{ml}$ of a (1:100) dilution was inoculated into $19 \mathrm{ml}$ of molten nutrient agar, properly mixed and poured into a sterile Petri
Table 1. Total bacteria viable count from well water samples in the Bambui student residential area.

\begin{tabular}{ccc}
\hline Samples & $\begin{array}{c}\text { Total bacteria viable } \\
\text { counts CFU/ML } \times 10^{4}\end{array}$ & $\begin{array}{c}\text { Total bacteria viable } \\
\text { counts CFU/100 ML }\end{array}$ \\
\hline W1C & 0.9 & 900,000 \\
W2C & 0.2 & 200,000 \\
W3C & 1.4 & $1,400,000$ \\
W4O & 6.9 & $6,900,000$ \\
W5O & 1.5 & $1,500,000$ \\
W6C & 0.8 & 800,000 \\
W7O & 2.6 & $2,600,000$ \\
W8O & 1.8 & $1,800,000$ \\
W9O & 7.1 & $7,100,000$ \\
W10O & 2.9 & $2,900,000$ \\
W11O & 6.2 & $6,200,000$ \\
W12O & 4.5 & $4,500,000$ \\
W13C & 0.4 & 400,000 \\
W14O & 7.3 & $7,300,000$ \\
W15C & 1.3 & $1,300,000$ \\
\hline
\end{tabular}

$\mathrm{W}=$ well samples $(1-15) .(\mathrm{C})=$ covered wells. $(\mathrm{O})=$ open wells.

dish. The agar was allowed to set, and then incubated at $37^{\circ} \mathrm{C}$ for 24 hours. The formed colonies were counted and result expressed as $\mathrm{cfu} / \mathrm{ml}$.

\subsection{Presumptive Coliform Test}

The multiple tube fermentation technique as described by Collins and Lynne [3] and Mackie and Mc cartney [4] was used. In this method, varying amounts of water sample were added to double and single strength Mac Conkey broth in sterile tubes as follows.

- $3 \times 10 \mathrm{ml}$ water sample to $5 \mathrm{ml}$ double strength medium

- $3 \times 1 \mathrm{ml}$ water sample to $3 \mathrm{ml}$ single strength medium

- $3 \times 0.1 \mathrm{ml}$ water sample to $3 \mathrm{ml}$ single strength medium

The bottles were incubated aerobically at $37^{\circ} \mathrm{C}$ for 24 48 hours after which they were examined for production of acid and gas. Sterile distilled water was used as a negative control for each test batch. Presumptive coliform count was obtained by the most probable number (MPN) of coliform per $100 \mathrm{ml}$ of water sample by making reference to the most probable number table after combination of various positive and negative results.

The presumptive coliform count measured by the most probable number per $100 \mathrm{ml}$ in the multiple tube fermentation technique of bacterial enumeration from the cover- 
ed and uncovered well water sources from the Bambui student residential area, are indicated in Table 2. The most probable number MPN per $100 \mathrm{ml}$ for the well water sample ranged between 3 and 1100+. Three water samples had an MPN within the standards limit set by the WHO while the rest twelve had an MPN which clearly exceeded the standard limit set by the World Health Organization (WHO). Table 3 shows bacterial pathogens isolated from well water sources from the Bambui student residential area.

Twelve (80\%) well water samples from the tested location were with one or more species of bacterial pathogen.

Klebsiella species were the most predominant (73.3\%) in the well water samples, followed by Salmonella (60\%), Escherichia coli (46.7\%), Enterobacter species (26.7\%) and Proteus mirabilis (6.7\%). The distribution of organism at the Bambui student residential area in Figures 1-3, Salmonella was absent in water samples W1C, W2C, W4O, W6O, W8O, and W13C. The distribution of organisms in covered and uncovered wells samples (Table 3) showed that Salmonella typhi was encountered in 9 samples out of 15 samples from both covered and uncovered wells making a percentage infection of $60 \%$. Its occurrence is greater in uncovered wells than in the covered wells.

Table 2. Presumptive coliform count from well water sample in the Bambui student residential area.

\begin{tabular}{|c|c|c|c|c|}
\hline \multirow{2}{*}{ Sample } & \multicolumn{3}{|c|}{$\begin{array}{l}\text { Number of tubes giving } \\
\text { positive reaction out of }\end{array}$} & \multirow{2}{*}{$\begin{array}{l}\text { MPN index } \\
\text { per } 100 \mathrm{ml}\end{array}$} \\
\hline & $\begin{array}{l}3 \text { of } 10 \mathrm{ml} \\
\text { each }\end{array}$ & $\begin{array}{l}3 \text { of } 1 \mathrm{ml} \\
\text { each }\end{array}$ & $\begin{array}{c}3 \text { of } 0.1 \mathrm{ml} \\
\text { each }\end{array}$ & \\
\hline W1(C) & 2 & 1 & 0 & 15 \\
\hline W2(C) & 0 & 0 & 0 & 3 \\
\hline W3(C) & 3 & 3 & 0 & 240 \\
\hline W4(O) & 3 & 3 & 3 & $>1100$ \\
\hline W5(O) & 3 & 2 & 0 & 93 \\
\hline W6(C) & 1 & 1 & 0 & 7.4 \\
\hline W7(O) & 3 & 1 & 2 & 120 \\
\hline W8(O) & 3 & 2 & 0 & 93 \\
\hline w9(O) & 3 & 3 & 3 & $>1100$ \\
\hline W10(O) & 3 & 2 & 1 & 150 \\
\hline W11(O) & 3 & 3 & 2 & 1100 \\
\hline W12(O) & 3 & 3 & 1 & 460 \\
\hline W13(C) & 0 & 0 & 0 & 3 \\
\hline W14(O) & 3 & 3 & 3 & $>1100$ \\
\hline W15(C) & 3 & 2 & 2 & 210 \\
\hline
\end{tabular}

$\mathrm{W}=$ well samples $(1-15) .(\mathrm{C})=$ covered wells. $(\mathrm{O})=$ open wells.
Table 3. Distribution of bacterial pathogen isolated from water samples in the Bambui student residential area.

\begin{tabular}{|c|c|}
\hline Sample & Identified isolates \\
\hline W1(C) & Enterobacter species \\
\hline W2(C) & No growth \\
\hline W3(C) & $\begin{array}{l}\text { Klebsiella species } \\
\text { Salmonella species }\end{array}$ \\
\hline W4(O) & $\begin{array}{l}\text { Klebsiella species } \\
\text { Enterobacter species }\end{array}$ \\
\hline W5(O) & $\begin{array}{l}\text { Escherichia coli } \\
\text { Klebsiella species } \\
\text { Salmonella species }\end{array}$ \\
\hline W6(C) & Klebsiella species \\
\hline W7(O) & $\begin{array}{c}\text { Escherichia coli } \\
\text { Klebsiella species } \\
\text { Salmonella species } \\
\text { Enterobacter species }\end{array}$ \\
\hline W8(O) & $\begin{array}{c}\text { Escherichia coli } \\
\text { Enterobacter species }\end{array}$ \\
\hline W9(O) & $\begin{array}{l}\text { Klebsiella species } \\
\text { Salmonella species }\end{array}$ \\
\hline W10(O) & $\begin{array}{l}\text { Escherichia coli } \\
\text { Klebsiella specie } \\
\text { Salmonella species }\end{array}$ \\
\hline W11(O) & $\begin{array}{l}\text { Klebsiella species } \\
\text { Proteus mirabilis } \\
\text { Salmonella species }\end{array}$ \\
\hline W12(O) & $\begin{array}{l}\text { Escherichia coli } \\
\text { Klebsiella species } \\
\text { Salmonella species }\end{array}$ \\
\hline W13(C) & No growth \\
\hline W14(O) & $\begin{array}{l}\text { Escherichia coli } \\
\text { Klebsiella species } \\
\text { Salmonella species }\end{array}$ \\
\hline W15(C) & $\begin{array}{l}\text { Escherichia coli } \\
\text { Klebsiella species } \\
\text { Salmonella species }\end{array}$ \\
\hline
\end{tabular}

$\mathrm{W}=$ well samples $(1$ - 15). (C) = covered wells. $(\mathrm{O})$ = open wells.

\section{Discussion of Results}

The spread of diseases through fecal contamination of water sources particularly in developing and under developed countries are a common phenomenon that has been well reported [2,6-9]. In the Bambui student residential area as well as most part of Cameroon, availability of treated pipe-borne water is rare and restricted where it exist to urban and semi-urban areas. Even in these areas, public water supply is quite irregular. Consequently rich individuals dig boreholes as alternative water sources. The poor or average classes which consti- 


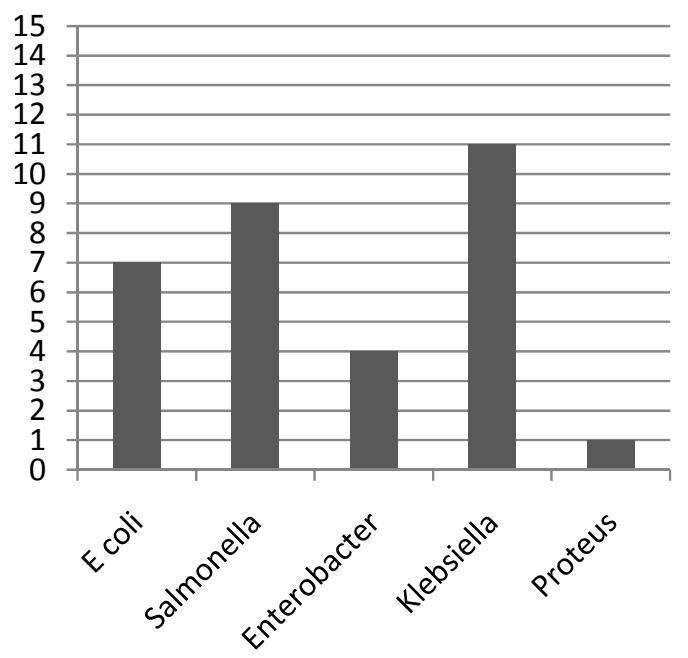

Figure 1. Bar chart showing the degree of contamination of water samples.

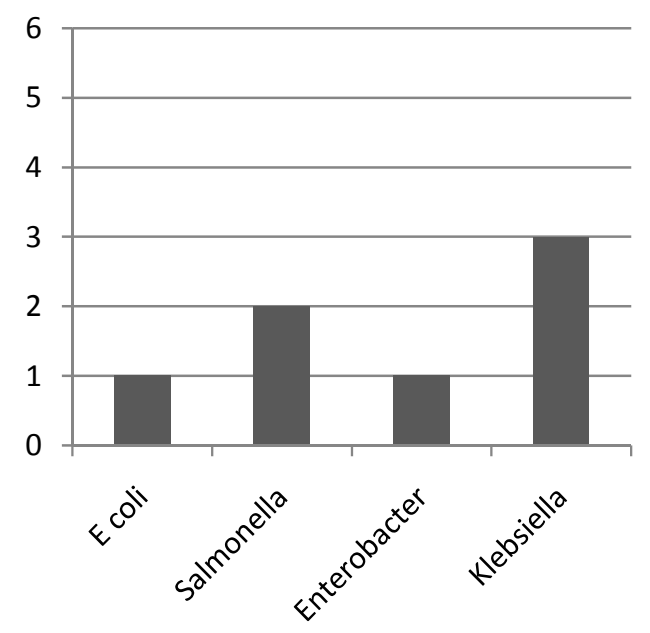

Figure 2. Bar chart showing distribution of organisms from covered well.

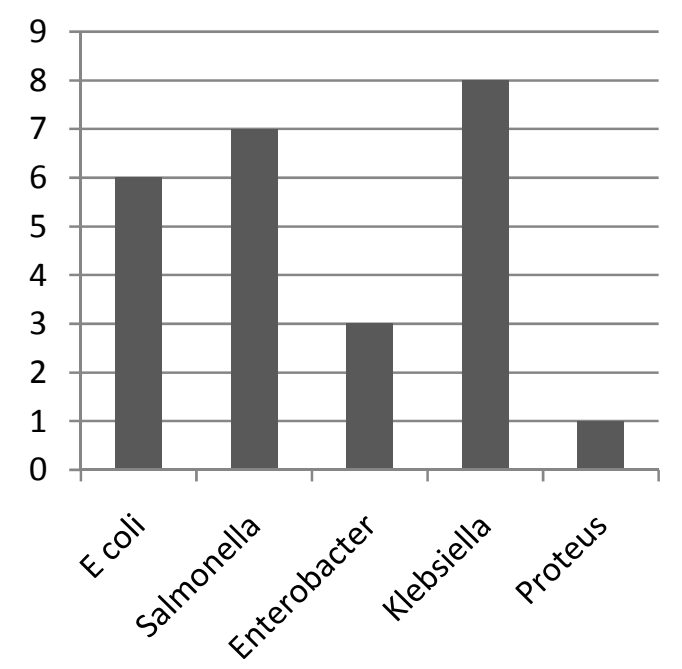

Figure 3. Bar chart showing distribution of organisms from uncovered well. tute more than $80 \%$ of the population which cannot afford the high cost of borehole drilling are forced to dig wells as alternative source of water supply for drinking and sanitary purpose. The viable bacterial count which is a measure of the microbial load of the water sample obtained in this study $\left(0.2-7.3 \times 10^{4} \mathrm{cfu} / \mathrm{ml}\right)$ exceeded the recommended limit $(<500 \mathrm{cfu} / \mathrm{ml})$. This shows that the wells contain very high level of microbial contaminant that make water obtained from them a threat to public health. The values obtained for the samples from the uncovered well were higher than the ones from the covered well. This is expected possibly due to the openness of the wells which permits unhindered access of particles from the surroundings compared to the covered wells. However, the sanitary quality of potable water is determined primarily by the kinds of micro-organisms present rather than by the microbial count [10].

The most probable number (MPN) per $100 \mathrm{ml}$ obtained for the well water samples $(3-1100+)$ clearly exceeded standard limit set by WHO. This suggest that the well water samples have been contaminated by potentially dangerous micro-organism and are therefore not fit for drinking purposes. This was confirmed by the characterization of the isolates from the well water samples from the locations under study which were highly contaminated with one or more bacterial pathogens namely Escherichia coli, Klebsiella species, Enterobacter species, Proteus mirabilis and Salmonella species. The most predominant is that the enteric coli forms Klebsiella species (73.3\%) followed by Salmonella typhi (66.7\%), Escherichia coli (53.3\%), Enterobacter species (26.7\%) and Proteus mirabilis (6.7\%).

These are pathogenic organisms mainly of fecal origin. Any water source used for drinking or cleaning purpose should not contain any organism of fecal origin [10]. Presence of enteric coliforms especially Escherichia coli makes the water samples unsuitable for human consumption according to the guidelines set by WHO for the evaluation of bacteriological quality of drinking water [2]. Apart from environmental hygiene and population density, the presence of Salmonella species in some of the covered and uncovered wells in this area may also be attributed to drainage and flooding from contaminated surface water into unprotected well shafts. Findings from this study clearly highlight the non conformity of well water samples studied with the WHO standard recommendation for safe potable water [8]. A situation where enteric pathogens are grossly isolated from sources of water consumed by humans is a serious problem which calls for vigilance on the part of the authorities as it signals possible future outbreak of water borne diseases. Such disease outbreaks may spread widely within the country and even possibly extend to neighboring countries since Cameroon shares boundaries with many West 
African states. The reason for the gross contamination of well water sources by pathogens as observed in this study may be due to openness and shallowness of the wells which allows easy entrance of particles from the surroundings. It may also be due to poor sanitary condition around the areas where such wells are located or drawing water from the wells with contaminated containers, a practice that is common among the users since individuals bring along their own water containers in some cases. The high morbidity that is recorded from enteric diseases such as diarrhea, dysentery and typhoid fever in the country may be due to wide spread consumption of contaminated well water.

\section{Conclusion}

This study has shown that there is a high incidence of contamination of well waters by pathogenic organisms. To reduce the wide spread incidence of contamination of well water, it is advocated that wells dug must be deep and covered adequately. Also good and proper personal and environmental sanitary practices must be maintained in and around the wells. Boiling well water before being used for drinking purposes and also the use of filters would also go a long way to prevent incidence of waterborne diseases.

\section{REFERENCES}

[1] A. Lamikanra, "Essential Microbiology for Students and
Practitioners of Pharmacy, Medicine and Microbiology," 2nd Edition, Amkra Books, 1999.

[2] World Health Organization, "Guidelines for Drinking Water Quality: Health Criteria and Other Support Information,” 1996, pp. 18-97.

[3] C. R. Collins and P. M. Lynes, "Microbiology Method," 4th Edition, Butterworth Press, London, 1976, pp. 271275.

[4] T. J. Mackie and J. E. McCartney, "Practical Medical Micryobiology,” In: J. C. College, J. P. Dugluid, A. G. Frasor and B. P. Marmion, Eds., Church Living Stone Publication, 1989, $910 \mathrm{p}$.

[5] S. T. Cowan and S. Steel, "Manual for Identification of Medical Bacterial. Cambridge University, Cambridge, 1993.

[6] M. Carrero-Colón and R. F. Turco, “Tracking Microbial Pathogens,” 2006.

[7] World Health Organization, "Guideline for DrinkingWater Quality," Surveillance and Control of Community Supplies, Vol. 3, No. 4-16, 1997, pp. 96-219.

[8] M. W. Lechevalier, C. D. Cawthon and R. G. Lee, "Factors Promoting Survival of Bacteria in Chlorinated Water Supplies,” Applied Environmental Microbiology, Vol. 88, 1987, pp. 649-554.

[9] O. A. Olowe et al., "Bacteriological Quality of Water Samples in Osogbometropolis," African Journal of Clinical and Experimental Microbiology, Vol. 6, No. 3, 2005, pp. 219-222.

[10] G. J. Bonde, "Bacterial Indication of Water Pollution in Advances in Aquatic Microbiology,” Academic Press, London, 1977. 